\title{
Foundational Leadership Theory: An Ethical Leadership Approach to Developing Positive Employee Work Engagement
}

\author{
LaJuan Perronoski Fuller \\ Trident University International, Cypress, CA, USA \\ Email: lajuan.fuller@my.trident.edu
}

How to cite this paper: Fuller, L. P. (2021). Foundational Leadership Theory: An Ethical Leadership Approach to Developing Positive Employee Work Engagement. Open Journal of Business and Management, 9, 2136-2151.

https://doi.org/10.4236/ojbm.2021.95113

Received: July 11, 2021

Accepted: August 16, 2021

Published: August 19, 2021

Copyright ( 2021 by author(s) and Scientific Research Publishing Inc. This work is licensed under the Creative Commons Attribution International License (CC BY 4.0).

http://creativecommons.org/licenses/by/4.0/

\begin{abstract}
Organizational commitment has a significant positive association with employee work engagement. Comparatively, organizational leaders recognize the value and competitive advantage of inspiring employee work engagement for sustainability in their industry. Numerous studies confirm that ethical leadership predicts organizational commitment. However, as of 2019, research suggested that alternative ethical leadership theories were needed to explain the influence on work engagement better. This study aimed to investigate the predictive power of Foundational Leadership Theory (FLT) developed by Fuller in 2021. FLT is an inward (internal) and outward (employee perceived) examination of ethical decisions based on integrity, assurance, and pragmatism. The findings were based on responses from 248 full-time employees across various industries in the United States of America. Pearson correlation and regression analysis revealed that integrity, assurance, and pragmatism predicted positive employee work engagement. FLT is a new theory and advances our understanding of employee commitment and work engagement in an organization. Human resource managers (HRM) recognized that employee enthusiasm is reflected in their work engagement. Therefore, leaders who rely on FLT are more likely to maintain a competitive advantage by creating or improving employee enthusiasm and engagement on the job.
\end{abstract}

\section{Keywords}

Ethical Leadership, Organizational Commitment, Work Engagement, Leadership Theories

\section{Introduction}

Human resources (HR) and business management scholars recognize "work en- 
gagement" as a primary topic for building an organization (Shuck et al., 2013). Work engagement is defined as employees' motivation and connection to their work (Bakker et al., 2013). Previous research suggested that work engagement is reflected by enthusiasm and supports organizational commitment (Macey \& Schneider, 2008). Studies confirmed these findings using the ethics position theory and identified that ethical leadership was equally responsible for predicting work engagement (Breevaart et al., 2015; DeCuypere \& Schaufeli, 2018). However, there is a need for alternative ethical leadership theories to help explain the connection between work engagement (van Knippenberg \& Sitkim, 2013; Pohan et al., 2019).

Work engagement has materialized as a valuable competitive advantage for organizations (Schaufeli et al., 2002). Enthusiastic employees have high work engagement, which inspires coworkers (Bakker \& Xanthopoulou, 2009) and improves organizational commitment (Aboramadan et al., 2019). Organizational commitment is an "attitudinal" approach and has emerged as the most significant predictor of employees' behaviors and actions (Zimmerman et al., 2020). Comparatively, ethical leadership predicts work engagement (DeCuypere \& Schaufeli, 2018) and organizational commitment (Aboramadan et al., 2020). However, there is a gap in the literature on alternative ethical theories on work engagement (Pohan et al., 2019). This research aims to introduce an alternative ethical theory developed by Fuller (2021) called Foundational Leadership Theory (FLT) to explain the ethical connection better to work engagement.

FLT advances the ethic position theory (EPT) and suggests that ethical leaders evaluate decisions based on integrity, assurance, and pragmatism. FLT consisted of a 15-item scale and received a previous Cronbach's alpha score was 0.93 using guidelines established by George and Mallery (2018). As a result, FLT significantly predicted organizational commitment (Fuller, 2021). Comparatively, FLT may further our understanding of work engagement (van Knippenberg \& Sitkim, 2013). Therefore, if integrity, assurance, and pragmatism (FLT) account for ethical leadership, then FLT will positively influence work engagement.

RQ1: Does FLT have a positive relationship with employee work engagement?

\section{Literature Review}

The foundational leadership theory (FLT) is ethical leadership based on an inward (personal) and outward (employee perception) approach. FLT builds on the ethic position theory (Forsyth, 1980), grounded on the works of Kohlberg (1976) and Piaget (1932). FLT suggests that employees perceive leaders as ethical when decisions have integrity, assurance, and pragmatism (Fuller, 2021). Research confirmed that integrity (FLI), assurance (FLA), and pragmatism (FLP) are perceived as ethical and predicted organizational commitment. This investigation previously supported findings that ethical leadership is a significant predictor of organizational commitment (Aboramadan et al., 2019). Thus, FLT's theoretical framework that predicted organizational commitment (Fuller, 2021) 
should influence work engagement.

\subsection{Foundational Leadership-Integrity}

Leaders with a high moral self are motivated to act and make ethical decisions (Jennings, Mitchell, \& Hannah, 2015). Research confirmed that fairness is highly associated with integrity and is considered an essential trait of ethical leadership (Brown \& Trevino, 2005). Nonetheless, there is still a lack of agreement on defining integrity (Leicht-Deobald, Busch, Schank, Weibel, Schafheitle, Wildhaber, \& Kasper, 2019). Leaders perceived as having integrity are viewed by employees as trustworthy, caring, honest, and fair (Jordan et al., 2017) and enhanced follower perception (Ming et al., 2020). Integrity was confirmed as a significant component of leadership (Palanski \& Yammarino, 2009) and contributed to predicting organizational commitment (Fuller, 2021). FLT measured integrity using a 5-item scale which contributed to developing an ethical leader. Therefore, FLT accounts for integrity and should have a positive association with work engagement.

\subsection{Foundational Leadership-Assurance}

Moral sensitivity influences moral stress (Sparks \& Hunt, 1998; Reynolds, 2008; Daniels, Diddams, \& Van Duzer, 2011). Trevino et al. (2003) concluded that moral stress produced anxiety and uncertainty among employees. Brown and Trevino (2005) suggested that employees can experience different levels of stress. Higher stress levels reduced productivity and job performance (Halkos \& Bousinkas, 2010; Shahid et al., 2012; Shukla \& Srivastava, 2016). FLT suggests that leaders who use assurance will account for employee stress and uncertainty (Fuller, 2021). This relationship is similar to previous research that revealed organizational employees perceived ethical leaders as a reflection of moral attentiveness, awareness, and identity (Lützén, Blom, Ewalds-Kvist, \& Winch, 2010). Therefore, FLT is a suitable alternative for leaders to measure ethical behaviors based on assurance to reduce stress and anxiety, which may better explain the connection to work engagement.

\subsection{Foundational Leadership-Pragmatism}

The social exchange theory (SET) suggested that a one-size-fits-all approach is not productive for organizational leadership and labeled pragmatism as fundamental to decision-making (Homans, 1961). Pragmatism is a reflective quality (Jordan, 2019) and emerges as routine in ethical leadership decision-making (Winter, 2013). Furthermore, pragmatic forms of leadership are positively related to high employee dedication (Anderson \& Sun, 2017). FLT advances the social exchange theory (SET) through pragmatism. FLP suggests that ethical leaders who routinely help employees meet or exceed goals are pragmatic. As a result, FLT predicting organizational commitment (Fuller, 2021) by incorporating pragmatism may help explain ethical leadership's influence on work engagement. 


\subsection{Work Engagement}

FLT research was mostly done on organizational commitment. However, work engagement is conceptually different from organizational commitment. Work engagement overtly refers to an employee's voluntary behavioral aspects at work (De Clercq et al., 2014). Demerouti et al. (2015) suggest that work engagement is an intrinsic motivation based on enthusiasm in employee work activities. This research confirms Schaufeli et al. (2002) that work engagement is an affective, cognitive state that may explain its influence on organizational commitment.

Studies have shown that work engagement positively influences employee job satisfaction, organizational commitment, innovation, and performance (Agarwal, 2014; Lu et al., 2014; Yalabik et al., 2015). Additionally, work engagement has been shown to influence organizational trust (Ugwu et al., 2014), self-regulation behaviors (De Clercq et al., 2014), personality traits (Woods \& Sofat, 2013), and learning goal orientation (Adriaenssens et al., 2015; Jones et al., 2017; Matsuo, 2019). Therefore, it is reasonable that ethical leadership may predict work engagement based on these organizational outcomes.

Schaufeli et al. (2002) describe work engagement as an employee's positive, fulfilling state of mind, measured by vigor, dedication, and absorption. Schaufeli et al. (2002) developed a 17-item Utrecht Work Engagement Scale (UWES). However, Schaufeli, Bakker and Salanova (2006) shorten UEWS to a 9-item scale, the most widely used scale for engagement, has become one of the most acknowledged conceptualizations of work engagement (Saks \& Gruman, 2014; Kulikowski \& Orezechowski, 2019). The UWES 9-item scale has been validated in research by Hewlin, Dumas and Burnett (2017) and Eldor and Vigoda-Gadot (2016). Therefore, Schaufeli et al. (2006) 9-item was proven to be an acceptable framework to study work engagement. However, more research is needed to reveal how other ethical leadership styles may impact employee enthusiasm measured by work engagement.

\subsection{Leadership Styles on Work Engagement}

Leadership has been shown to encourage positive attitudes from employees (Bhal \& Ansari, 2007). Leadership is defined as an interpersonal communication system that guides employees toward organizational goals (Birasnav, 2014). Influential leaders can influence followers toward achieving organizational outcomes (Hentrich et al., 2017). Comparatively, leadership traits such as transformational and transactional compel employees to meet organizational goals and predict behaviors (Zigarmi et al., 2004). Transformational and transactional leadership has been some of the most studied leadership theories in organizational literature (Woods \& King, 2012). However, more research is needed to reveal how other ethical leadership styles may impact employee enthusiasm measured by work engagement.

Bakker et al. (2013) defined work engagement as the level of an employee's motivation and positive connection to their work. As a result, much attention 
has been given to factors influencing work engagement (Aboramadan et al., 2020; Aboramadan et al., 2019). Comparatively, engagement has been shown to increase organizational commitment and improve employee mental health (Rana et al., 2014; Schaufeli, 2014; Robertson \& Cooper, 2010). Transformational (Li et al., 2018) and transactional leadership (Amor et al., 2020; Ghadi et al., 2013; Hawkes et al., 2017) are linked to work engagement. However, Bass $(1985 ; 1998)$ suggests that leaders who lack inspiration but communicate expectations can increase work engagement. Communication is crucial in decreasing employee uncertainty, stress, and anxiety which degrades job productivity (Shukla \& Srivastava, 2016).

Charismatic leaders inspire, motivate, and intellectually stimulate employees (Aboramadan \& Dahleez, 2020). Additionally, the leadership type has been shown to predict organizational behavior (Lee, 2005; Hassi, 2018) and high job performance (Jing, 2018). Transactional leadership sets objectives, defines employee roles, and promotes achievements through rewards (Kanungo, 2001; Deichmann \& Stam, 2015). Charismatic and transactional leaders influence organizational commitment (Jabeen et al., 2015) and organizational effectiveness (Bass \& Riggio, 2005). FLT has a similar affect on organizational commitment (Fuller, 2021). However, more research is needed to determine FLT's ability to explain enthusiasm that inspires employees toward levels of work engagement.

The social exchange theory (SET) explained the link between transformational and transactional leadership on employee behavior and attitudes (Breevaart \& Bakker, 2018; Buckingham \& Coffman, 2014). SET revealed that leadership styles improve employees' dedication to the organization based on pragmatism (Anderson \& Sun, 2017) and are essential in ethical decision-making (Fuller, 2021). Theoretical studies support employees who perceive transactional leaders as "fair" have positive work-related behaviors and attitudes (Aboramadan \& Dahleez, 2020). This theoretical study confirmed Brown and Trevino (2005), which suggested that fairness is observed as an integrity trait and influenced organizational commitment (Ming et al., 2020). Because employee behaviors and enthusiasm are reflected by work engagement, the FLT theoretical framework of integrity, assurance, and pragmatism propose the following hypothesis (Figure $1)$.

H0: FLT has no association with employee work engagement.

H1: FLT has a positive association with employee work engagement.

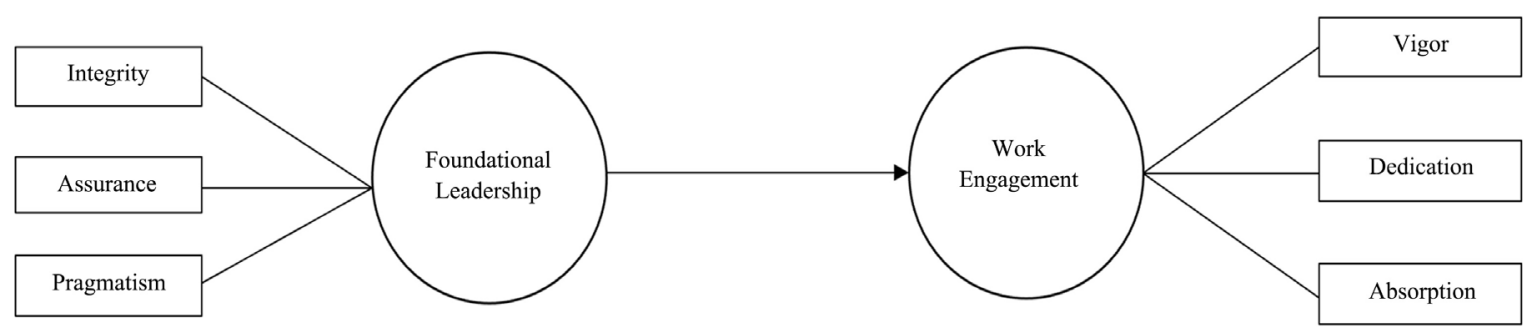

Figure 1. Foundational leadership and work engagement conceptual model. 


\section{Methodology}

This methodology section describes the overall validity and reliability of the independent variable (IV) FLT and dependent variable (DV) work engagement. This cross-sectional, quantitative study collected and analyzed data to study the relationship between FLT and work engagement. The IV is measured using a 15-item scale by Fuller (2021) and a 9-item scale by Schaufeli et al. (2006). Only full-time employee work data was used from the U.S. Department of Labor, current as of April 2020. The U.S. workforce is estimated at approximately 136 million (not including seasonal or holiday employees).

Cronbach's alpha was used to measure the scale reliability of the Likert-type scales. Next, Pearson correlation was used to represent relationships between the FLT and WE. The results tested the assumptions of normality, homoscedasticity, outliers, and regression paths. Since there was only one predictor variable, multicollinearity does not apply, and Variance Inflation Factors (VIF) were not calculated. Finally, linear regression analysis was used to compare the positive or negative strength between the FLT and WE to confirm the measurement model.

\section{Definition of Terms}

FLT measures perceived integrity, assurance, and pragmatism for ethical leaders. Therefore, ethical decisions grounded in FLT will significantly predict employee work engagement. FLT consisted of a 15-item scale developed and validated by Fuller (2021) on a seven-point Likert typed measurement scale. For example, "I trust leadership decisions that promote job security." Each measurement was based on a seven-point Likert-typed scale $(1=$ strongly disagree, $7=$ strongly agree) with a previous Cronbach's alpha of 0.93 .

Foundational Leadership Integrity. Integrity is perceived fairness and significantly correlates with ethical leadership and organizational commitment. Thus, FLI is measured using a 5-item scale and indicated their extent of agreement with each item on a seven-point Likert-typed scale $(1=$ strongly disagree, $7=$ strongly agree). For example, 1) leadership decisions should NOT be based on receiving personal gifts and money. 2) My leader's decisions should NOT be based on unsupported personal opinions. 3) My leader's decision should NOT be based on receiving personal favors in return.

Foundational Leadership Assurance. FLA measures leadership decisions that reassure employees. FLA is measured using a 5-item scale. The respondents indicated their extent of agreement with each item on a seven-point Likert-typed scale ( 1 = strongly disagree, 7 = strongly agree). For example, 1) I trust leadership decisions that promote job security. 2) I trust leadership decisions that consider the amount of anxiety their decisions may cause. 3) I trust leadership decisions when they are not confusing, unclear, and uncomplicated.

Foundational Leadership Pragmatism. FLP suggests that leadership decisions should be practical, easy to understand and help employees met professional and organizational goals. The extent of agreement with each item is based on a sev- 
en-point Likert-typed scale ( $1=$ strongly disagree, $7=$ strongly agree). For example 1) I believe leadership decisions should help employees meet and/or exceed organizational goals. 2) I believe leadership decisions should be realistic and achievable on the job. 3) I should be able to apply leadership decisions on the job.

Work Engagement. Work engagement was measured using a 9-item scale developed and validated by the Utrecht Work Engagement Scale (UWES) (Schaufeli et al., 2006; Schaufeli, 2014). The UWES assesses work engagement by vigor, dedication, and absorption. For example, "At my work, I feel bursting with energy" (vigor), "I am proud of the work that I do" (dedication), and "I get carried away when I'm working" (absorption) rated on a seven-point Likert-type scale ranging $(1=$ Never, $7=$ Always $)$ with a previous Cronbach's alpha of 0.87 . Item scales are found in Table 1.

Control Variable. Gender differences can affect ethical judgment, decisions, behavior (Fuller, 2021). Previous research has shown that gender did not have significant correlations with outcome variables. Therefore, this study will replicate Fuller's (2021) control variable to provide further insight on gender in this study.

\section{Method of Analysis}

This quantitative study collected and analyzed data from 289 participants to investigate FLT and work engagement. The results of this study were based on 249 completed surveys from full-time employees in the United States. Part-time or seasonal employees or self-employed persons did not participate. The survey was sent via SurveyMonkey ${ }^{\mathrm{TM}}$; each participant was randomly selected and required to read instructions before responding to the survey. Participants who selected "I do not agree" were not given access to the survey and were diverted to a screen stating, “Thank you for your participation." Participants who agreed to participate were given access to the survey after signed informed consent. Each response was given under anonymous conditions, and no personally identifiable information (PII) was collected. The survey asked respondents to indicate a level

Table 1. Definition of terms.

\begin{tabular}{ll}
\hline Measurement & Definition \\
\hline Foundational Leadership-Integrity & $\begin{array}{l}\text { Fairness in decision-making is not based on biases, personal } \\
\text { favors, gifts, and/or unsupported opinions (Fuller, 2021). }\end{array}$ \\
Foundational Leadership-Assurance & $\begin{array}{l}\text { Leadership decisions reassure employees by promoting job } \\
\text { security and reducing anxiety/stress (Fuller, 2021). }\end{array}$ \\
Foundational Leadership Pragmatism & $\begin{array}{l}\text { Easy to understand and practical decisions that help } \\
\text { employees meet/exceed organizational goals (Fuller, 2021). }\end{array}$ \\
Work Engagement & $\begin{array}{l}\text { The level of an employee's motivation and positive } \\
\text { connection to their work (Schaufeli et al., 2006; Bakker et } \\
\text { al., 2013; Schaufeli, 2014) }\end{array}$ \\
\hline
\end{tabular}


of agreement of FLT based on a 7-point Likert scale $(1=$ strongly disagree to $7=$ strongly agree $)$ and on WE ( 1 = Never, 7 = Always). Cronbach's alpha was used to validate each scale. Additionally, Pearson correlation was used to recognize potential positive relationships between FLT and work engagement. Finally, linear regression was used to establish the predictive power of FLT on work engagement.

\section{Results}

Summary statistics were calculated based on responses from 249 participants from various industries throughout the US. Participants answered questions to measured FLT and Work Engagement. A summary of statistics for FLT (integrity, assurance, and pragmatism) and Work Engagement (vigor, dedication, and absorption) can be found in Table 2.

A Cronbach alpha coefficient was calculated for the FLT and Work Engagement. This was done to ensure that each question effectively measured each construct before conducting an overall FLT measurement. The Cronbach's alpha coefficient was evaluated using the guidelines suggested by George and Mallery (2018) where $>0.9$ excellent, $>0.8$ good, $>0.7$ acceptable, $>0.6$ questionable, $>0.5$ poor, and $\leq 0.5$ unacceptable. FLI, FLA, and FLP were $>0.8$ or higher. Table 3 represents the Cronbach Alpha results.

FLT 15-items were transformed into FLT and the 9-items into Work Engagement. A Pearson correlation analysis was conducted between FLT. All assumptions were met for Pearson Correlation testing per Conover and Iman (1981). A significant positive correlation was observed between FLT and Work Engagement $(\mathrm{RP}=0.29, p<0.001,95 \% \mathrm{CI}[0.17,0.40])$. The correlation coefficient between FLT and WE was 0.29. This correlation indicates that as FLT increases, Work Engagement tends to increase. Table 4 presents the results of the correlation.

A linear regression analysis was conducted to assess whether FLT significantly predicted Work Engagement. All assumptions of normality, homoscedasticity, multicollinearity, and outliers were met. The results of the linear regression model were significant and indicated that FLT significantly predicted work engagement, $\mathrm{B}=0.20, \mathrm{t}(246)=4.77, p<0.001$. This indicates that a one-unit increase of FLT will increase the value of work engagement by 0.20 units on average. Table 5 summarizes the results of the regression model.

Table 2. Summary statistics table for interval and ratio variables.

\begin{tabular}{ccccccc}
\hline Variable & $\mathrm{M}$ & $\mathrm{SD}$ & $\mathrm{n}$ & $\mathrm{SE}_{\mathrm{M}}$ & Min & Max \\
\hline FLI & 30.84 & 6.05 & 248 & 0.38 & 5.00 & 35.00 \\
FLA & 35.26 & 6.48 & 248 & 0.41 & 6.00 & 42.00 \\
FLP & 29.52 & 5.39 & 248 & 0.34 & 5.00 & 35.00 \\
Vigor & 13.31 & 3.81 & 248 & 0.24 & 3.00 & 21.00 \\
Dedication & 14.46 & 4.50 & 248 & 0.29 & 3.00 & 21.00 \\
Absorption & 14.14 & 3.88 & 248 & 0.25 & 3.00 & 21.00 \\
\hline
\end{tabular}


Table 3. Reliability table for FLT and work engagement.

\begin{tabular}{ccccc}
\hline Variable & Item & $\alpha$ & Lower Bound & Upper Bound \\
\hline FLT & 15 & 0.95 & 0.94 & 0.96 \\
Work Engagement & 9 & 0.93 & 0.91 & 0.94 \\
\hline
\end{tabular}

Table 4. Pearson correlation results for FLT and work engagement.

\begin{tabular}{cccc}
\hline Combination & RP & $95 \%$ CI & $p$ \\
\hline FLT-Work Engagement & 0.29 & {$[0.17,0.40]$} & $<0.001$ \\
\hline
\end{tabular}

Table 5. Linear regression results for FLT and work engagement.

\begin{tabular}{ccccccc}
\hline Variable & $\mathrm{B}$ & $\mathrm{SE}$ & $\mathrm{CI}$ & $\beta$ & $\mathrm{t}$ & $p$ \\
\hline (Intercept) & 23.49 & 3.92 & {$[15.77,31.21]$} & 0.00 & 5.99 & $<0.001$ \\
FLT & 0.20 & 0.04 & {$[0.12,0.29]$} & 0.29 & 4.77 & $<0.001$ \\
\hline
\end{tabular}

Table 6 summarizes the hypothesis testing results for FLT and Work Engagement.

An analysis of variance (ANOVA) was conducted to determine whether there were significant differences in work engagement by gender. The ANOVA was examined based on an alpha value of 0.05 . The results of the ANOVA were not significant, $\mathrm{F}(1,246)=1.78, p=0.184$, indicating the differences in work engagement among the levels of gender were all similar (Table 7).

The main effect, gender, on work engagement was not significant, $\mathrm{F}(1,246)=$ 1.78, $p=0.184$, indicating no significant differences in male and female work engagement. The means and standard deviations are presented in Table 8 . There were no significant effects in the model. As a result, posthoc comparisons were not conducted.

\section{Discussion}

This study has two theoretical contributions. First, FLT filled gaps in the literature on alternative ethical theories that may further explain work engagement (Breevaart et al., 2015; DeCuypere \& Schaufeli, 2018). FLT builds on EPT by predicting work engagement and organizational commitment. This provides a better understanding of how ethical leadership influences employee enthusiasm. Whereas leadership decision-making grounded in integrity, assurance, and pragmatism encourages work engagement. Linear regression results indicated that leaders who approach ethics using an inward (personal) and outward (employee perceived) examination would more likely positively affect employee work commitment.

Furthermore, FLT consist of integrity, assurance, and pragmatism, which suggest that leaders will more likely have more committed (Fuller, 2021) and enthusiastic employees. Secondly, this study advanced literature on SET. SET 
Table 6. Hypothesis testing results for FLT and work engagement.

\begin{tabular}{ccc}
\hline Variable & B & SE \\
\hline H1:FLT significantly predicts Work Engagement & $p<0.001$ & Accepted \\
\hline
\end{tabular}

Table 7. Analysis of variance table for work engagement by gender.

\begin{tabular}{cccccc}
\hline Term & SS & df & F & $p$ & $\eta_{p}^{2}$ \\
\hline Gender & 216.82 & 1 & 1.78 & 0.184 & 0.01 \\
Residuals & $29,996.05$ & 246 & & & \\
\hline
\end{tabular}

Table 8. Mean, standard deviation, and sample size for work engagement by gender.

\begin{tabular}{cccc}
\hline Combination & $\mathrm{M}$ & $\mathrm{SD}$ & $\mathrm{n}$ \\
\hline Male & 42.95 & 10.85 & 110 \\
Female & 41.07 & 11.19 & 138 \\
\hline
\end{tabular}

suggested that pragmatism is essential in predicting employee behaviors. Pragmatism is an attribute of FLT and predicted organizational commitment (Fuller, 2021). Pragmatism is a reflective nature and fundamental in leadership decision-making (Jordan, 2019). Therefore, pragmatic leadership encourages organizational commitment (Anderson \& Sun, 2017) and explains why FLT predicted work engagement in this study. Pearson correlation confirmed that including pragmatism as an attribute of ethical leadership will significantly and positively affect employee work engagement.

There are practical implications based on this investigation. First, Cronbach's alpha score confirmed previous studies by Fuller (2021) that integrity, assurance, and pragmatism effectively measured FLT. Additionally, this study confirmed that vigor, dedication, and absorption constructs by Schaufeli et al. (2006) and Schaufeli (2014) are still a reliable measurement scale for work engagement. Pearson correlation results suggest that employees' enthusiasm has a positive relationship with employee perception of leadership attributes based on integrity, assurance, and pragmatism. This advances our understanding of why employee enthusiasm is reflected in work engagement.

Furthermore, FLT predicted organizational commitment and confirmed that similar constructs should influence work engagement (Shuck et al., 2013; Bakker et al., 2013). Next, the literature suggested there was a need for alternative theories to understand work engagement better. FLT significantly predicts work engagement which proposes that leaders who use internal (personal) and external (employee perception) evaluation through the ethical lens of integrity, assurance, and pragmatism will likely improve work engagement among employees.

Finally, FLT confirmed the research on work engagement by van Knippenberg and Sitkim (2013), Pohan et al. (2019), Jordan et al. (2017), and Ming et al. (2020). FLT findings revealed that fairness is still perceived as integrity and encourages positive work engagement. Therefore, ethical leaders promote work 
engagement (Aboramadan \& Dahleez, 2020) and should examine decisions through the lens of integrity, assurance, and pragmatism.

\section{Conclusion}

The research findings suggest that HR and business managers should consider FLT ethical leadership practices to influence work engagement. The results indicated that FLT has a positive association to work engagement. Additionally, linear regression analysis revealed that FLT predicted work engagement. Therefore, organization leaders can improve organizational commitment and work engagement using FLT integrity, assurance, and pragmatism. Organization leaders should consider using FLT in addition to relying on other known methods. This ensures that decisions are more likely to increase work engagement based on this alternative ethical decision-making approach.

This research has limitations based on using a cross-sectional study method. Therefore, the relationship between FLT and work engagement may change over time. The 248 participants in this study might have yielded different ANOVA results if race, income level, or time on the job had been used as controls. Therefore, these are areas that should be considered in further studies.

There were possible sample biases in this investigation. First, it was impossible to measure the entire population; data were collected from a sample consisting of 248 full-time employees to reduce this bias and fall within an acceptable margin of error. Participants could have rushed or not have answered each question thoroughly. To mitigate this possibility, the survey contained only 27 one-sentence items to address variables. Furthermore, each item was derived from previously validated and accepted studies to decrease survey bias.

Further research is needed on how FLT may mediate or moderate the relationship between other ethical leadership practices and work engagement. Additionally, studies on other alternative ethical leadership styles may contribute to a deeper understanding of organizational commitment and WE. Gender was examined and showed no significant effect. Therefore, more research is needed to determine how other demographic categories such as race and income level may influence work engagement.

Shukla and Srivastava (2016) suggest that communication is crucial in decreasing employee uncertainty, stress, and anxiety. FLT uses the construct of assurance to account for and reduces these factors. Therefore, FLT advanced the ethics position theory and revealed that ethical leadership is equally responsible for predicting work engagement (Breevaart et al., 2015; DeCuypere \& Schaufeli, 2018). In conclusion, FLT contributed to the need for alternative ethical leadership theories to advance our understanding of the positive association with work engagement (van Knippenberg \& Sitkim, 2013; Pohan et al., 2019).

\section{Conflicts of Interest}

The author declares no conflicts of interest regarding the publication of this paper. 


\section{References}

Aboramadan, M., Albashiti, B., Alharazin, H., \& Dahleez, K. A. (2020). Human Resources Management Practices and Organizational Commitment in Higher Education: The Mediating Role of Work Engagement. International Journal of Educational Management, 34, 154-174. https://doi.org/10.1108/IJEM-04-2019-0160

Aboramadan, M., \& Dahleez, K. (2020). Leadership Styles and Employees' Work Outcomes in Nonprofit Organizations: The Role of Work Engagement. Journal of Management Development, 39, 869-893. https://doi.org/10.1108/JMD-12-2019-0499

Aboramadan, M., Hassi, A., Alharazin, H. J., Dahleez, K. A., \& Albashiti, B. (2019). Volunteering Drivers and Continuation Will: The Role of Engagement. Journal of Management Development, 38, 405-420. https://doi.org/10.1108/JMD-02-2019-0057

Adriaenssens, J., De Gucht, V., \& Maes, S. (2015). Association of Goal Orientation with Work Engagement and Burnout in Emergency Nurses. Journal of Occupational Health, 57, 151-160. https://doi.org/10.1539/joh.14-0069-OA

Agarwal, U. A. (2014). Linking Justice, Trust and Innovative Work Behaviour to Work Engagement. Personnel Review, 43, 41-73. https://doi.org/10.1108/PR-02-2012-0019

Amor, M. A., Abel Vazquez, J. P., \& Faíña, J. A. (2020). Transformational Leadership and Work Engagement: Exploring the Mediating Role of Structural Empowerment. European Management Journal, 38, 169-178. https://doi.org/10.1016/j.emj.2019.06.007

Anderson, M., \& Sun, P. (2017). Reviewing Leadership Styles: Overlaps and the Need for a New Full Range Theory. International Journal of Management Reviews, 19, 76-96. https://doi.org/10.1111/ijmr.12082

Bakker, A. B., Derks, D., \& van Rhenen, W. (2013). Job Crafting at the Team and Individual Level: Implications for Work Engagement and Performance. Group and Organization Management, 38, 427-454. https://doi.org/10.1177\%2F1059601113492421

Bakker, A. B., \& Xanthopoulou, D. (2009). The Crossover of Daily Work Engagement: Test of an Actor-Partner Interdependence Model. Journal of Applied Psychology, 94, 1562-1571. https://doi.apa.org/doi/10.1037/a0017525

Bass, B. M. (1985). Leadership and Performance Beyond Expectations (1st ed.). Free Press.

Bass, B. M. (1998). Transformational Leadership: Industrial, Military, and Educational Impact. Lawrence Erlbaum Associates. https://books.google.com.om/books?id57zqsNAEACAAI

Bass, B. M., \& Riggio, R. E. (2005). Transformational Leadership (2nd ed.). Psychology Press. https://doi.org/10.4324/9781410617095

Bhal, K. T., \& Ansari, M. A. (2007). Leader-Member Exchange-Subordinate Outcomes Relationship: Role of Voice and Justice. Leadership and Organization Development Journal, 28, 20-35. https://doi.org/10.1108/01437730710718227

Birasnav, M. (2014). Relationship between Transformational Leadership Behaviors and Manufacturing Strategy. International Journal of Organizational Analysis, 22, 205-223. https://doi.org/10.1108/IJOA-10-2011-0520

Breevaart, K., \& Bakker, A. B. (2018). Daily Job Demands and Employee Work Engagement: The Role of Daily Transformational Leadership behavior. Journal of Occupational Health Psychology, Educational Publishing Foundation, 23, 338-349. https://doi.apa.org/doi/10.1037/ocp0000082

Breevaart, K., Bakker, A. B., Demerouti, E., \& van den Heuvel, M. (2015). Leader-Member Exchange, Work Engagement, and Job Performance. Journal of Managerial 
Psychology, 30, 754-777. https://doi.org/10.1108/JMP-03-2013-0088

Brown, M., \& Trevino, L. (2005). Ethical Leadership: A Social Learning Perspective for Construct Development and Testing. Organizational Behavior and Human Decision Processes, 97, 117-134. https://doi.org/10.1016/j.obhdp.2005.03.002

Buckingham, M., \& Coffman, C. (2014). First, Break All the Rules: What the World's Greatest Managers Do Differently. Gallup Press.

https://books.google.com.om/books?id5mo67BwAAQBAJ

Conover, W. J., \& Iman, R. L. (1981). Rank Transformations as a Bridge between Parametric and Nonparametric Statistics. The American Statistician, 35, 124-129. https://doi.org/10.1080/00031305.1981.10479327

Daniels, D., Diddams, M., \& Van Duzer, J, (2011). A Magnetic Pull on the Internal Compass: The Moderating Effect of Response to Culture on the Relationship between Moral Identity and Ethical Sensitivity. Journal of Religion and Business Ethics, 2, Article No. 3. https://via.library.depaul.edu/jrbe/vol2/iss $2 / 3$

De Clercq, D., Bouckenooghe, D., Raja, U., \& Matsyborska, G. (2014). Servant Leadership and Work Engagement: The Contingency Effects of Leader-Follower Social Capital. Human Resource Development Quarterly, 25, 183-212. https://doi.org/10.1002/hrdq.21185

DeCuypere, A., \& Schaufeli, W. (2018). Positive Leadership Styles and Engagement: A Meta-Analysis and Review. Manuscript Submitted for Publication.

Deichmann, D., \& Stam, D. (2015). Leveraging Transformational and Transactional Leadership to Cultivate the Generation of Organization-Focused Ideas. The Leadership Quarterly, 26, 204-219. https://doi.org/10.1016/j.leaqua.2014.10.004

Demerouti, E., Bakker, A. B., \& Gevers, J. M. P. (2015). Job Crafting and Extra-Role Behavior: The Role of Work Engagement and Flourishing. Journal of Vocational Behavior, 91, 87-96. https://doi.org/10.1016/j.jvb.2015.09.001

Eldor, L., \& Vigoda-Gadot, E. (2016). The Nature of Employee Engagement: Rethinking the Employee-Organization Relationship. The International Journal of Human Resource Management, 28, 526-552. https://doi.org/10.1080/09585192.2016.1180312

Forsyth, D. R. (1980). A Taxonomy of Ethical Ideologies. Journal of Personality and Social Psychology, 39, 175-180. https://content.apa.org/doi/10.1037/0022-3514.39.1.175

Fuller, L. (2021). Foundational Leadership Theory: The Inward and Outward Approach to Examine Ethical Decision-Making. Open Journal of Leadership, 10, 79-94. https://doi.org/10.4236/ojl.2021.102006

George, D., \& Mallery, P. (2018). IBM SPSS Statistics 25 Step by Step. Routledge. https://doi.org/10.4324/9781351033909

Ghadi, M. Y., Fernando, M., \& Caputi, P. (2013). Transformational Leadership and Work Engagement: The Mediating Effect of Meaning in Work. Leadership and Organization Development Journal, Emerald, 34, 532-550. https://doi.org/10.1108/LODJ-10-2011-0110

Halkos, G., \& Bousinakis, D. (2010). The Effect of Stress and Satisfaction on Productivity. International Journal of Productivity and Performance Management, 59, 415-431. https://doi.org/10.1108/17410401011052869

Hassi, A. (2018). 'You Get What You Appreciate' Effects of Leadership on Job Satisfaction, Affective Commitment and Organisational Citizenship Behavior. International Journal of Organizational Analysis, 27, 756-811.

https://doi.org/10.1108/IJOA-08-2018-1506 
Hawkes, A. J., Biggs, A., \& Hegerty, E. (2017). Work Engagement: Investigating the Role of Transformational Leadership, Job Resources, and Recovery. The Journal of Psychology, 151, 509-531. https://doi.org/10.1080/00223980.2017.1372339

Hentrich, S., Zimber, A., Garbade, S. F., Gregersen, S., Nienhaus, A., \& Petermann, F. (2017). Relationships between Transformational Leadership and Health: The Mediating Role of Perceived Job Demands and Occupational Self-Efficacy. International Journal of Stress Management, Educational Publishing Foundation, 24, 34-61. https://doi.apa.org/doi/10.1037/str0000027

Hewlin, P. F., Dumas, T. L., \& Burnett, M. F. (2017). To Thine Own Self Be True? Facades of Conformity, Values Incongruence, and the Moderating Impact of Leader Integrity. Academy of Management Journal, 60, 178-199. https://doi.org/10.5465/amj.2013.0404

Homans, G. C. (1961). Social Behavior: Its Elementary Forms. Harcourt Brace Jovanovich.

Jabeen, F., Behery, M., \& Abu Elanain, H. (2015). Examining the Relationship between the Psychological Contract and Organisational Commitment: The Mediating Effect of Transactional Leadership in the UAE Context. International Journal of Organizational Analysis, 23, 102-122. https://doi.org/10.1108/IJOA-10-2014-0812

Jennings, P. L., Mitchell, M. S., \& Hannah, S. T. (2015). The Moral Self: A Review and Integration of the Literature. Journal of Organizational Behavior, 36, S104-S168. https://doi.org/10.1002/job.1919

Jing, F. F. (2018). Leadership Paradigms and Performance in Small Service Firms. Journal of Management and Organization, 24, 339-358. https://doi.org/10.1017/jmo.2017.44

Jones, J. L., Davis, W. D., \& Thomas, C. H. (2017). Is Competition Engaging? Examining the Interactive Effects of Goal Orientation and Competitive Work Environment on Engagement. Human Resource Management, 56, 389-405.

https://doi.org/10.1002/hrm.21773

Jordan, G., Miglič, G., Todorović, I., \& Marič, M. (2017). Psychological Empowerment, Job Satisfaction and Organizational Commitment among Lecturers in Higher Education: Comparison of Six CEE Countries. Organizacija, 50, 17-32. https://doi.org/10.1515/orga-2017-0004

Jordan, J. B. (2019). Meta-Engagement: An Examination of Employee Engagement Antecedent Variable Interactions and the Impact on Engagement Outcomes. Doctoral Dissertation, University of Louisville.

Kanungo, R. N. (2001). Ethical Values of Transactional and Transformational Leaders. Canadian Journal of Administrative Sciences, 18, 257-265. https://doi.org/10.1111/j.1936-4490.2001.tb00261.x

Kohlberg, L. (1976). Moral Stages and Moralization: The Cognitive-Developmental Approach. In T. Lickona (Ed.), Moral Development and Behavior: Theory, Research and Social Issues (pp. 31-53). Holt, Rinehart and Winston.

Kulikowski, K., \& Orzechowski, J. (2019). Working Memory and Fluid Intelligence as Predictors of Work Engagement-Testing Preliminary Models. Applied Cognitive Psychology, 33, 596-616. https://doi.org/10.1002/acp.3500

Lee, J. (2005). Effects of Leadership and Leader-Member Exchange on Commitment. Leadership and Organization Development Journal, 26, 655-672. https://doi.org/10.1108/01437730510633728

Leicht-Deobald, U., Busch, T., Schank, C., Weibel, A., Schafheitle, S., Wildhaber, I. et al. (2019). The Challenges of Algorithm-Based HR Decision-Making for Personal Integrity. Journal of Business Ethics, 160, 377-392. 
https://doi.org/10.1007/s10551-019-04204-w

Li, Y., Castan o, G., Li, Y., Li, Y., \& Li, Y. (2018). Linking Leadership Styles to Work Engagement: The Role of Psychological Capital among Chinese Knowledge Workers. Chinese Management Studies, 12, 433-452. https://doi.org/10.1108/CMS-04-2017-0108

Lu, C., Wang, H., Lu, J., Du, D., \& Bakker, A. B. (2014). Does Work Engagement Increase Person-Job Fit? The Role of Job Crafting and Job Insecurity. Journal of Vocational Behavior, 84, 142-152. https://doi.org/10.1016/j.jvb.2013.12.004

Lützén, K., Blom, T., Ewalds-Kvist, B., \& Winch, S. (2010). Moral Stress, Moral Climate and Moral Sensitivity among Psychiatric Professionals. Nursing Ethics, 17, 213-224. https://doi.org/10.1177\%2F0969733009351951

Macey, W. H., \& Schneider, B. (2008). The Meaning of Employee Engagement. Industrial and Organizational Psychology, 1, 3-30. https://doi.org/10.1111/j.1754-9434.2007.0002.x

Matsuo, M. (2019). Effect of Learning Goal Orientation on Work Engagement through Job Crafting: A Moderated Mediation Approach. Personnel Review, 48, 220-233. https://doi.org/10.1108/PR-11-2017-0346

Ming, X., Bai, X., \& Lin, L. (2020). Kick the Cat: A Serial Crossover Effect of Supervisors' Ego Depletion on Subordinates' Deviant Behavior. Frontiers in Psychology, 11, Article No. 1314. https://doi.org/10.3389/fpsyg.2020.01314

Palanski, M. E., \& Yammarino, F. J. (2009). Integrity and Leadership: A Multi-Level Conceptual Framework. Leadership Quarterly, 20, 405-420.

https://doi.org/10.1016/j.leaqua.2009.03.008

Piaget, J. (1932). The Moral Judgment of the Child. Free Press.

Pohan, V., Schaufeli, W., Ivanova, T., \& Osin, E. (2019). Basic Psychological Need Satisfaction Mediates the Relationship between Engaging Leadership and Work Engagement: A Cross-National Study. Human Resource Development Quarterly, 30, 453-471. https://doi.org/10.1002/hrdq.21366

Rana, S., Ardichvili, A., \& Tkachenko, O. (2014). A Theoretical Model of the Antecedents and Outcomes of Employee Engagement: Dubin's Method. Journal of Workplace Learning, 26, 249-266. https://doi.org/10.1108/JWL-09-2013-0063

Reynolds, S. J. (2008). Moral Attentiveness: Who Pays Attention to the Moral Aspects of Life? Journal of Applied Psychology, 93, 1027-1041. https://doi.apa.org/doi/10.1037/0021-9010.93.5.1027

Robertson, I. T., \& Cooper, C. L. (2010). Full Engagement: The Integration of Employee Engagement and Psychological Wellbeing. Leadership and Organization Development Journal, 31, 324-336. https://doi.org/10.1108/01437731011043348

Saks, A. M., \& Gruman, J. A. (2014). What Do We Really Know about Employee Engagement? Human Resource Development Quarterly, 25, 155-182. https://doi.org/10.1002/hrdq.21187

Schaufeli, W. B. (2014). What Is Engagement? In C. Truss, K. Alfes, R. Delbridge, A. Shantz, \& E. Soane (Eds.), Employee Engagement in Theory and Practice (pp. 15-35). Routledge.

Schaufeli, W. B., Bakker, A. B., \& Salanova, M. (2006). The Measurement of Work Engagement with a Short Questionnaire. Educational and Psychological Measurement, 66, 701-707. https://doi.org/10.1177\%2F0013164405282471

Schaufeli, W. B., Salanova, M., Gonzalez-Roma, V., \& Bakker, A. B. (2002). The Measurement of Engagement and Burnout: A Confirmative Analytic Approach. Journal of 
Happiness Studies, 3, 71-92. https://doi.org/10.1023/A:1015630930326

Shahid, M. N., Latif, K., Sohail, N., \& Ashraf, M. A. (2012). Work Stress and Employee Performance in Banking Sector Evidence from District Faisalabad Pakistan. Asian Journal of Business and Management Sciences, 1, 38-47.

Shuck, B., Ghosh, R., Zigarmi, D., \& Nimon, K. (2013). The Jingle Jangle of Employee Engagement: Further Exploration of the Emerging Construct and Implications for Workplace Learning and Performance. Human Resource Development Review, 12, 11-35. https://doi.org/10.1177\%2F1534484312463921

Shukla, A., \& Srivastava, R. (2016). Development of Short Questionnaire to Measure an Extended Set of Role Expectation Conflict, Coworker Support and Work-Life Balance: The New Job Stress Scale. Cogent Business \& Management, 3, Article No. 1. https://doi.org/10.1080/23311975.2015.1134034

Sparks, J., \& Hunt, S. (1998). Marketing Researcher Ethical Sensitivity: Conceptualization, Measurement, and Exploratory Investigation. Journal of Marketing, 62, 92-109. https://doi.org/10.1177\%2F002224299806200207

Trevino, L. K., Brown, M., \& Hartman, L. P. (2003). A Qualitative Investigation of Perceived Executive Ethical Leadership: Perceptions from Inside and Outside the Executive Suite. Human Relations, 56, 5-37. https://doi.org/10.1177\%2F0018726703056001448

Ugwu, F. O., Onyishi, I. E., \& Rodriguez-Sanchez, A. M. (2014). Linking Organizational Trust with Employee Engagement: The Role of Psychological Empowerment. Personnel Review, 43, 377-400. https://doi.org/10.1108/PR-11-2012-0198

van Knippenberg, D., \& Sitkin, S. B. (2013). A Critical Assessment of CharismaticTransformational Leadership Research: Back to the Drawing Board? The Academy of Management Annals, 7, 1-60. https://doi.org/10.5465/19416520.2013.759433

Winter, S. G. (2013). Habit, Deliberation, and Action: Strengthening the MICRO-Foundations of Routines and Capabilities. Academy of Management Perspectives, 27, 120-137. https://doi.org/10.5465/amp.2012.0124

Woods, R. H., \& King, J. Z. (2012). Leadership and Management in the Hospitality Industry (3rd ed.). Educational Institute of the American Hotel Motel Association.

Woods, S. A., \& Sofat, J. A. (2013). Personality and Engagement at Work: The Mediating Role of Psychological Meaningfulness. Journal of Applied Social Psychology, 43, 2203-2210. https://doi.org/10.1111/jasp.12171

Yalabik, Z. Y., van Rossenberg, Y., Kinnie, N., \& Swart, J. (2015). Engaged and Committed? The Relationship between Work Engagement and Commitment in Professional Service Firms. International Journal of Human Resource Management, 26, 1602-1621. https://doi.org/10.1080/09585192.2014.953972

Zigarmi, D., Blanchard, K., O’Connor, M., \& Edeburn, C. (2004). The Leader Within: Learning Enough about Yourself to Lead Others. FT Press.

Zimmerman, R., Swider, B., \& Arthur, J. (2020). Does Turnover Destination Matter? Differentiating Antecedents of Occupational Change versus Organizational Change. Journal of Vocational Behavior, 12, Article ID: 103470.

https://doi.org/10.1016/j.jvb.2020.103470 